УДК 336.719.2:340.134]:351.74

DOI https:// doi.org/10.32837 / yuv.v0i6.2063

Г. Кучерук,

ад'юнкт кафедри кримінального процесу

Національної академії внутрішніх справ

\title{
НОВИЙ ПОГЛЯД НА ПОРЯДОК РОЗКРИТТЯ БАНКІВСЬКОЇ ТАЕМНИЦІ ПРАВООХОРОННИМ ОРГАНАМ В КОНТЕКСТІ ОСТАННІХ ЗАКОНОДАВЧИХ ЗМІН
}

Постановка проблеми. Сучасний етап розвитку українського суспільства характеризується зростаючою роллю інформаційної сфери. Забезпечення правового захисту інтересів особи, суспільства, держави в інформаційній сфері є одним із пріоритетів національної політики України. Однак водночас світові тенденції деофшоризації, глобального обміну інформацією між правоохоронними, контролюючими органами та фінансовими установами піднімають питання використання інформації, яка містить банківську таємницю, оскільки засоби та форми скоєння злочинів різної спрямованості, зокрема інтернаціоналізація економічних злочинів та відмивання доходів, одержаних злочинним шляхом, накладають свій відбиток на практичну діяльність правоохоронних органів, які здійснюють досудове розслідування під час вирішення питань, пов'язаних з отриманням ними інформації, яка містить банківську таємницю.

Однак, виходячи з того, що необхідною умовою нормального функціонування комерційних банків є збереження банківської таємниці для забезпечення стабільного та ефективного їх функціонування, держава передбачила такий правовий інститут, як банківська таємниця, який $€$ невід'ємною складовою частиною правової системи кожної розвинутої країни світу, особливості якої залежать від правової системи певної дер- жави та визначаються особливостями економіко-правової системи.

В усіх демократичних державах інститут банківської таємниці являє собою показник збалансованості інтересів особи, держави та суспільства, підстав та умов втручання держави у сферу приватних інтересів, приватного та публічного права, тому залежно від того, наскільки ефективно та повно врегульовані питання взаємодіi державних правоохоронних органів та банківських установ щодо порядку та обсягу отримання інформації, що містить банківську таємницю, настільки ефективно буде здійснюватися боротьба зі злочинністю, витримуючи баланс приватних та держаних інтересів.

Банківська діяльність як різновид комерційної діяльності держави та недержавних підприємств, установ та організацій регулює обіг державних та приватних фінансів 3 використанням обігу певної інформації, держателями якої є банківські установи, а визначені законом державні органи виступають як суб'єкти, наділені певним правом згідно із законом вимагати інформацію, яка містить банківську таємницю.

Крім того, сучасна актуалізація питань легалізації коштів, отриманих злочинним шляхом, зростання міжнародного тероризму та розмаїття шляхів та засобів його фінансування на цьому етапі розвитку інституту банківської таємниці у світовому 
просторі ведуть до деабсолютизації банківської таємниці як недоторканої банківської інформації як такої, тому ця проблема потребує законодавчого вдосконалення та регулювання задля одностайного тлумачення та правильного застосування.

Аналіз останніх досліджень та публікацій (оцінка стану літератури). Проблеми тлумачення, визначення сутності та правового режиму банківської таємниці розглядались у працях таких учених, як А.Ю. Вікулін, В.Н. Лопатін, В.А. Копилов. Деякі кримінально-процесуальні аспекти інституту банківської таємниці висвітлені у працях О.М. Ларіна, Я.О. Мотовіловкера, О.О. Самсонової та інших авторів. У сучасній кримінально-процесуальній літературі окремі питання правозастосовних норм, регулюючих питання отримання та використання органами досудового розслідування інформації, яка містить банківську таємницю та використання ї̈ у кримінальному процесі й процесі доказування, висвітлені у працях таких вітчизняних та зарубіжних учених, як В.О. Голубєв, Д.О. Гетманцев, A.I. Марущак, А.О. Шаповалова, С.С. Чернявський, Р.А. Калюжний.

Враховуючи безумовну цінність зазначених наукових праць та проведених досліджень, визнаємо, що у сучасних реаліях функціонування суспільно-економічних відносин інституту банківської таємниці, а також межам та підставам втручання правоохоронних органів приділено недостатньо уваги. Крім того, останнім часом в Україні було прийнято низку нормативно-правових актів, якими врегульовано правовий режим банківської таємниці згідно з міжнародно-правовими стандартами та суттєво спрощено механізм і процедуру отримання правоохоронними органами інформаціi, яка містить банківську таємницю.

Метою статті $€$ спроба проаналізувати особливості сучасного правового регулювання порядку розкриття інформації, що містить банківську таємницю, правоохоронним органам з урахуванням останніх змін у законодавстві України; визначення недоліків, які виникають під час застосування законодавства.

Виклад основного матеріалу. Згідно зі ст. 32 Конституції України, ніхто не може зазнавати втручання в його особисте і сімейне життя, крім випадків, передбачених Конституцією України. Не допускається збирання, зберігання, використання та поширення конфіденційної інформації про особу без їі згоди, крім випадків, визначених законом, і лише в інтересах національної безпеки, економічного добробуту та прав людини [1].

У сучасному суспільстві проблемі та законодавчому регулюванню особистих прав і свобод людини в контексті кримінально-процесуальних відносин приділено значну увагу задля встановлення балансу між ними та межами втручання й мірою обмеження них державою. Саме тому у правових відносинах такого характеру, які виникають між фізичними та юридичними особами та уповноваженими правоохоронними органами держави, у процесі здійснення останніми своїх владних повноважень існують певні правові інститути, регулювання який відображає ступінь досконалості правового регулювання державою прав та свобод людини. Саме інститут банківської таємниці $€$ одним із таких зразкових показників, тому, як правильно зазначає О.О. Самсонова, саме інститут банківської таємниці являє собою лакмусовий папірець балансу інтересів особистості, суспільства та держави, приватного та публічного права, підстав та меж втручання держави у недержавну сферу, ступеня інформаційної захищеності особистості [2, с. 4].

У цьому аспекті неможливо не погодитися також 3 висновком O.В. Фаткіної про те, що інститут банківської таємниці $є$ публічно-правовим інститутом, кінцева мета якого 
полягає у забезпеченні стабільності банківської системи держави, іiі безпечного й ефективного функціонування. Публічно-правовий інститут банківської таємниці $€$ сукупністю правових норм, що регулюють однорідні суспільні відносини, що виникають, розвиваються та функціонують у сфері забезпечення конфіденційності відомостей, що становлять банківську таємницю [3, с. 21].

Аналізуючи законодавство України, яке прямо чи опосередковано регламентує інформацію, що містить банківську таємницю та регулює ії правовий режим, зазначаємо, що в контексті розвитку інформаційних відносин у сучасному суспільстві та подальшого його формування інформація 3 обмеженим доступом викликає особливий інтерес і відіграє значну роль у його функціонуванні. Аналізуючи визначення поняття «персональні дані» та ї правовий режим згідно із Законом України «Про захист персональних даних», зазначаємо, що таємниця вкладів, рахунків та операцій по них, персональні дані клієнтів з елементами таємниці особистого життя належать до персональної інформації, поширення якої без згоди ії власника заборонено законодавством [4]. У сфері економіко-фінансової діяльності суспільства саме така інформація, що містить банківську таємницю, належить до інформації з обмеженим доступом.

Крім того, банківська таємниця, згідно із Законом України «Про інформацію», є різновидом конфіденційної інформації, тобто це інформація про фізичну особу, а також інформація, доступ до якої обмежено фізичною або юридичною особою, крім суб'єктів владних повноважень, яку можна поширювати за згодою особи у визначеному нею порядку. Стосовно банківської таємниці, то така інформація зберігається в банківській установі, клієнтом якої є фізична та юридична особа з огляду на договірні та довірливі відносини [5].
Необхідність удосконалення законодавства, що регулює банківську таємницю, обумовлена тим, що, згідно з ч. 4 ст. 2 Закону України «Про національну безпеку України», державна політика у сферах національної безпеки й оборони спрямовується на забезпечення воєнної, зовнішньополітичної, державної, економічної, інформаційної, екологічної безпеки, кібербезпеки України тощо, де забезпечення державної та економічної безпеки полягає насамперед у вжитті певних антикорупційних заходів, які припускають певну фінансову прозорість ділового обігу у вигляді послаблення режиму банківської таємниці та прагнення держави до європейського прикладу викорінення корупції в Україні, виявлення правопорушників та притягнення винних до відповідальності [6].

Серед інших законів, що регламентують правовий режим банківської таємниці, слід назвати Цивільний кодекс України, Закон України «Про банки та банківську діяльність». Під час вирішення питань щодо отримання інформації, що містить банківську таємницю, зокрема під час проведення досудового розслідування, слід керуватися відповідними положенням Кримінально-процесуального кодексу України, Податкового кодексу України, Законами України «Про інформацію», «Про Національний Банк України», «Про оперативно-розшукову діяльність», «Про доступ до публічної інформації», «Про Національну поліцію України», «Про запобігання та протидію легалізації (відмиванню) доходів, одержаних злочинним шляхом, фінансуванню тероризму та фінансуванню розповсюдження зброї масового знищення», «Про організаційно-правові основи боротьби 3 організованою злочинністю» тощо.

Стаття 60 Закону України «Про банки та банківську діяльність» визначає, що інформація щодо діяльності та фінансового стану клієнта, 
яка стала відомою банку у процесі обслуговування клієнта та взаємовідносин з ним чи третім особам під час надання послуг банку, є банківською таємницею [7].

Банківською таємницею, зокрема, $€$ відомості про банківські рахунки клієнтів, у тому числі кореспондентські рахунки банків у Національному банку України; операції, які були проведені на користь чи за дорученням клієнта, здійснені ним угоди; фінансово-економічний стан клієнтів; системи охорони банку та клієнтів; інформація про організаційно-правову структуру юридичної особи, а саме клієнта, ї керівників, напрями діяльності; відомості стосовно комерційної діяльності клієнтів чи комерційної таємниці, будь-якого проєкту, винаходів, зразків продукції та інша комерційна інформація; інформація щодо звітності по окремому банку, за винятком тієї, що підлягає опублікуванню; коди, що використовуються банками для захисту інформації; інформація про фізичну особу, яка має намір укласти договір про споживчий кредит, отримана під час оцінювання іï кредитоспроможності. Інформація про банки чи клієнтів, що збирається під час проведення банківського та валютного нагляду, становить банківську таємницю [7].

Таким чином, законодавець дає однозначне визначення банківської таємниці та окреслює обсяг такої інформації, який не дозволяється обмежувати чи, навпаки, розширювати, тобто перелік такої інформації $€$ вичерпним.

У сучасних реаліях соціально-політичного та економічного життя держави та суспільства розуміння абсолютності банківської таємниці вже не $€$ таким усталеним та абсолютним у тому аспекті, що будь-яка інформація практично не могла бути наданою зацікавленим особам, окрім власників цієї інформації, або надана у зовсім обмеженому вигляді на запити уповноважених державних органів.
Проте в останнє десятиріччя розвинені країни почали помітно змінювати підхід до цього правила. Для України це пов'язано з кроками імплементаціï Конвенції з протидії розмивання бази оподаткування та виведення прибутку 3-під оподаткування, відомої як BEPS (Base Erosion and Profit Shifting). Вважається, що такі кроки дадуть змогу зменшити виток капіталів із країн та нормалізують податкові надходження. 3 урахуванням цього країнам, які приєднались до BEPS, стануть відомі всі рахунки у всіх країнах щодо конкретної особи. Для вирішення цієї проблеми було створено механізми автоматичного обміну інформацією (CRS - Common Reporting Standards) між банками, податковими органами, фінансово-моніторинговими установами в автоматичному режимі на щорічній основі, до реалізації якого Україна невдовзі буде залучена.

Щодо України, як правильно зауважив М.В. Корнієнко, потребує чіткого законодавчого визначення з урахуванням світового досвіду проблема обмеження банківської таємниці та інших відповідних правил, які діють у фінансових установах, а також забезпечення активнішої ролі фінансових установ у протидії організованій злочинності. Становище, яке склалося $з$ цього питання в банківський системі України, суперечить положенням міжнародних конвенцій, нормам і правилам Євросоюзу та об'єктивно сприяє приховуванню коштів, здобутих злочинним шляхом, та скоєнню інших корисливих злочинів [8, с. 345].

Отже, 31 жовтня 2019 року було прийнято Закон України «Про внесення змін до деяких законодавчих актів України щодо конфіскації незаконних активів осіб, уповноважених на виконання функцій держави або місцевого самоврядування, i покарання за придбання таких активів», згідно з яким були внесені зміни до Закону України «Про банки та 
банківську діяльність», яким було змінено порядок та підстави отримання інформації, яка складає банківську таємницю.

Вже у грудні 2019 року Національний банк України Постановою Правління Національного банку України від 31 січня 2020 року № 13 змінив процедуру розкриття банківської таємниці, змінивши норми збереження, використання та розкриття банківської таємниці відповідно до Закону, прийнятого 31 жовтня 2019 року, змінивши таким чином порядок розкриття банківської таємниці відповідно до ст. 62 Закону України «Про банки і банківську діяльність». Зокрема, було спрощено порядок розкриття банківської таємниці на запит органів прокуратури, СБУ, ДБР, Національної поліції, НАБУ, Антимонопольного комітету України.

Право відповідних правоохоронних органів на отримання інформації, що містить банківську таємницю, випливає також зі ст. 93 КПК України, згідно з якою сторона обвинувачення здійснює збирання доказів як шляхом проведення слідчих (розшукових) дій, так і шляхом витребування та отримання від органів державної влади, підприємств, установ та організацій, службових та фізичних осіб речей, документів та відомостей, які мають значення для кримінального провадження шляхом надання відповідного запиту, який, згідно із законом, $€$ обов'язковим для виконання [9].

Відповідно до п. п. 3, 3.1 та 3.2 ст. 62 Закону України «Про банки і банківську діяльність», інформація без судового рішення буде надаватися органам прокуратури України, Служби Безпеки України, Державного бюро розслідувань, Національної поліції, Національного антикорупційного бюро України, Антимонопольного комітету України на їх письмову вимогу [7].

Як бачимо, перелік цих органів чималий, проте він $є$ вичерпним, крім того, судовою практикою встанов- лено, що нормативно-правові акти, які регулюють діяльність цих органів, $є$ спеціальними щодо Закону «Про банки і банківську діяльність» згідно з Постановою Верховного Суду України від 20 лютого 2018 року у справі $910 / 8001 / 17$ [10].

Таким чином, розширено доступ до банківської таємниці для органів Національної поліції, прокуратури, Служби Безпеки, Державного бюро розслідувань, Антимонопольного комітету України та Національного антикорупційного бюро, що спростило механізм та порядок іï отримання. Відтепер для отримання доступу до банківської таємниці вже не потрібно отримати рішення суду, а достатньо лише звернутися 3 письмовим запитом до банку щодо операцій за рахунками конкретної юридичної або фізичної особи.

Однак варто зазначити, що кожен окремий державний орган отримав різний рівень доступу до банківської таємниці. Аналізуючи перелік правоохоронних та контролюючих органів, на вимогу яких банки повинні надавати інформацію, яка містить банківську таємницю та перелік законодавчо перелічених відомостей, що містять банківську таємницю, зауважуємо, що розкрити інформацію, що містить банківську таємницю, банк зобов'язаний лише в тих обсягах, які визначені законом для конкретного держоргану 3 урахуванням його компетенції. Всі інші відомості, які не названі у Законі «Про банки та банківську діяльність», які вимагаються компетентним державним органом на підставі запиту, повинні розглядатися як порушення права клієнта та конституційних прав, передбачених ст. 32 Конституції України.

Розглядаючи обсяг інформації, що містить банківську таємницю щодо окремо взятих правоохоронних органів згідно із законом, зазначаємо, що інформація, яка містить банківську таємницю, за письмовим запитом надаватиметься Прокуратурі, Службі

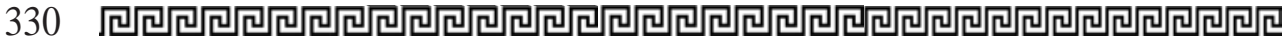


Безпеки України, Державному бюро розслідувань, Національній поліції, НАБУ, Антимонопольному комітету України лише про операції за рахунками конкретної юридичної особи чи фізичної особи-підприємця і за конкретний проміжок часу. Прокуратура, Державне бюро розслідувань, Національне антикорупційне бюро у справах, які стосуються виявлення необгрунтовано набутих активів, зможуть отримувати інформацію про банківські операції за рахунками конкретної фізичної особи, фізичної особи-підприємця чи компанії, а також у конкретний проміжок часу. Найширший доступ до відомостей, які становлять банківську таємницю, отримало Національне антикорупційне бюро, детективи якого отримали право витребувати без рішення суду інформацію стосовно рахунків, вкладів, правочинів, операцій за рахунками або без відкриття рахунків конкретної юридичної особи, ФОП або фізичної особи за конкретний проміжок часу із зазначенням контрагентів.

Незважаючи на те, що Закон «Про внесення змін до деяких законодавчих актів України щодо конфіскації незаконних активів осіб, уповноважених на виконання функцій держави або місцевого самоврядування, і покарання за набуття таких активів» стосується тільки представників влади, правила ст. 62 Закону України «Про банки та банківську діяльність», до якого внесені зміни, вже стосуються всіх юридичних та фізичних осіб.

Окрім того, ст. 62 Закону України «Про банки і банківську діяльність» була доповнена положенням, що дає змогу Національному банку України розкривати інформацію про банк чи пов'язаних із банком осіб, що збирається під час проведення банківського нагляду й становить банківську таємницю, на письмову вимогу органів державної влади, уповноважених здійснювати досудове розслідування, у разі виявлення порушення законодавства, що містить ознаки кримі- нального правопорушення, а також у справах щодо виявлення необгрунтованих активів та збирання доказів ï необгрунтованості [7].

Саме тому з'явилася потреба впорядкування норм Правил зберігання, захисту, використання та розкриття банківської таємниці, затверджених Постановою Правління Національного банку України від 14 липня 2006 року № 267. Необхідні зміни були затвердженні Постановою Правління Національного банку України від 31 січня 2020 року № 13 [11].

Порядок та межі розкриття банками інформації, що містить банківську таємницю, а також порядок вилучення (виїмки) речей і документів, які містять інформацію, що становить банківську таємницю, більш детально визначено у Постанові Правління Національного банку України «Про затвердження Правил зберігання, захисту, використання та розкриття банківської таємниці» від 14 липня 2006 року. Згідно з п. 3.3 зазначеної Постанови, банк у разі надходження до нього письмової вимоги про надання інформації, що містить банківську таємницю, зобов'язаний розкрити цю інформацію або дати мотивовану відповідь про неможливість надання відповідної інформації протягом 10 робочих днів з дня отримання вимоги, якщо інші строки не встановлені законодавством України [12].

Згідно з положеннями ст. 62 Закону України «Про банки та банківську діяльність», вимога відповідного державного органу на отримання інформації, яка містить банківську таємницю, повинна бути викладена на бланку державного органу встановленої форми або надіслана в електронному вигляді; бути надана за підписом керівника державного органу (чи його заступника), скріпленого гербовою печаткою, або бути завірена кваліфікованим електронним підписом керівника державного органу (чи його заступника); містити передбачені цим Законом підстави для отримання цієї інформації; містити посилання 
на норми закону, відповідно до яких державний орган має право на отримання такої інформації [7].

Банк відмовляє в розкритті інформації, що містить банківську таємницю, якщо за своєю формою або змістом вимога відповідного державного органу не відповідає нормам ч. 2 ст. 62 Закону про банки [12].

Належне оформлення відповідного запиту буде запорукою відсутності безпідставних відмов працівників банків у наданні інформаціі, що містить банківську таємницю.

Перелік відомостей, який може бути наданий на письмову вимогу правоохоронних органів, який передбачений ст. 62 Закону України «Про банки та банківську діяльність», містить вичерпний перелік інформації. Банк може абсолютно законно й обгрунтовано відмовити у наданні інформації, яка містить банківську таємницю, якщо правоохоронні органи у своєму запиті вимагають будь-яку іншу інформацію разом із даними, які перелічені у ст. 62 Закону України «Про банки і банківську діяльність».

За необхідності отримання відомостей, що містять банківську таємницю, які не перелічені у ст. 62 Закону України «Про банки та банківську таємницю» як такі, що можуть бути надані на підставі запиту, правоохоронні органи повинні звернутися до слідчого судді за дозволом про тимчасовий доступ до інформації, що містить банківську таємницю, згідно з вимогами гл. 15 Кримінально-процесуального кодексу України, і тільки після отримання відповідної ухвали слідчого судді звертатися до банку. Якщо звернення до суду було здійснено владним органом, передбаченим згаданою ст. 62 Закону України «Про банки та банківську діяльність», то суд має перевірити, чи було спершу реалізовано правоохоронним органом свої повноваження щодо звернення з вимогою до особи, яка володіє відповідними речами та документами, та причини відмови у наданні інфор- маціі, що містить банківську таємницю, а потім у порядку та відповідно до вимог, що регламентуються ст. ст. 163, 164 КПК України, ухвалити відповідне рішення.

Саме інститут тимчасового доступу до речей та документів уже неодноразово ефективно зарекомендував себе судовою практикою, якщо за власним запитом до банку уповноваженій особі правоохоронного органу було відмовлено у розкритті банківської таємниці. Згідно з ч. 1 ст. 165 КПК України, особа, яка зазначена в ухвалі слідчого судді, суду про тимчасовий доступ до речей і документів як володілець речей або документів, зобов'язана надати тимчасовий доступ до речей і документів особі, яка зазначена у відповідній ухвалі [9].

У будь-якому разі банк зобов'язаний виконувати вимоги судової ухвали. Наявність підстав для розкриття, належність суб'єкта звернення мають бути перевірені судом під час постановлення ухвали, на відміну від звернення до банку із запитами, коли законність має встановлюватися самим банком.

За невиконання ухвали про тимчасовий доступ до речей та документів, згідно з вимогами ст. 166 КПК Україн, слідчий суддя, суд за клопотанням сторони кримінального провадження, якій надано право на доступ до речей i документів на підставі ухвали, має право постановити ухвалу про дозвіл на проведення обшуку [9]. Обшук та огляд речей і документів, які містять інформацію, що становить банківську таємницю, їх тимчасове вилучення під час цих слідчих (розшукових) дій проводяться на підставі ухвали слідчого судді про дозвіл на обшук або огляд володіння особи та в порядку і з дотриманням вимог гл. 16 розд. II, ст. ст. 234-237 гл. 20 розд. III КПК України та норм Закону «Про банки і банківську діяльність, що забезпечують охорону банківської таємниці» [9].

Незважаючи на спрощення механізму отримання інформаціі, що містить 
банківську таємницю, чинне законодавство з цього питання потребує вдосконалення з точки зору насамперед відповідності меті ї запровадження, а не використання як засобу збору інформації з обмеженим доступом та безпідставної ревізії фізичних та юридичних осіб з боку правоохоронних та контролюючих органів. Крім того, спрощення такого доступу не має унеможливлювати в подальшому повноцінне використання отриманої на підставі вимоги відповідного правоохоронного органу інформації, що містить банківську таємницю, оскільки порядок отримання таких відомостей має відповідати процесуальній формі згідно 3 вимогами кримінально-процесуального законодавства та Закону України «Про банки і банківську діяльність».

Згідно 3 вимогами ст. 86 КПК України, доказ визнається допустимим, якщо він отриманий у порядку, встановленому цим Кодексом. Недопустимий доказ не може бути використаний під час прийняття процесуальних рішень, на нього не може посилатися суд під час ухвалення судового рішення [9].

На особливу увагу, на мій погляд, заслуговує чітка, детальна та правильна регламентація саме у законі підстав для отримання таких відомостей, які також мають бути чітко та детально описані у вимозі відповідного уповноваженого правоохоронного органу та містити посилання на норми закону, відповідно до яких правоохоронний орган має право на отримання такої інформації. Якщо у судовому порядку розкриття банківської таємниці судом здійснюються ретельна перевірка законності підстав звернення та аналіз наданих доказів, то надання інформації, що містить банківську таємницю на підставі запиту правоохоронного органу, може бути зведено лише до перевірки банком формального дотримання норм ч. 2 ст. 62 Закону Україні «Про банки і банківську діяльність» без жодного аналізу додаткових документів.
Однак у чинному законодавстві, що регламентує механізм отримання відомостей, що містять банківську таємницю, відсутнє чітке та детальне законодавче врегулювання підстав для отримання такої інформації, що, на мій погляд, буде сприяти необгрунтованим відмовам банківських та фінансових установ у наданні відомостей, що містять банківську таємницю, та не буде сприяти принципам процесуальної економії і вирішенню завдань кримінального провадження, які регламентовані у ст. 2 Кримінально-процесуального кодексу України.

Щодо цього слушно навести приклад законодавчого регулювання порядку та механізму отримання інформації, що містить банківську таємницю, у Республіки Казахстан. Закон Республіки Казахстан «Про банки і банківську діяльність у Республіці Казахстан» у ст. 50 вимагає зазначення мети інтересу до банківської таємниці фізичної та юридичної особи з боку органів національної безпеки, зокрема попередження, розкриття й припинення розвідувальних i (або) підривних акцій, а також вимога санкцій прокурора [13]. При цьому у Республіці Казахстан банківська таємниця може бути передана лише із санкції прокурора органам дізнання й попереднього слідства тільки по тих кримінальних справах, які перебувають у ї провадженні, і у випадках, коли на гроші та інше майно фізичної особи, що знаходяться на рахунках чи на зберіганні в банку, може бути накладено арешт, звернено стягнення або застосовано конфіскацію майна.

Аналогічний приклад детальної регламентації підстав отримання інформації, що містить банківську таємницю, можна знайти у ст. 121 Банківського кодексу Республіки Білорусь [14].

Вдосконалення порядку отримання інформації, що містить банківську таємницю, може відбутися шляхом внесення змін до Закону України «Про банки та банківську діяльність» 
у вигляді положення щодо детальної регламентації підстав отримання правоохоронними органами інформації, що містить банківську таємницю, а саме пряме посилання у законі на наявність інформації щодо кримінального правопорушення, вчиненого конкретною особою (юридичною чи фізичною), яке внесене до Єдиного реєстру досудових розслідувань.

Крім того, не можу не погодитися з пропозицією С.С. Чернявського та Д.О. Алєкєєвої-Процюк щодо доцільності врегулювання повноважень оперативних підрозділів стосовно розкриття інформації, що містить банківську таємницю, шляхом внесення змін до ст. 8 Закону України «Про оперативно-розшукову діяльність» прямої регламентації повноважень цих органів щодо строків, підстав та порядку отримання інформації, що містить банківську таємницю, однак у порядку, передбаченому ст. 21 КПК України [15]. Іншими словами, підставою для отримання державними органами відомостей, що становлять банківську таємницю, має бути не загальне повноваження державного органу запитувати у підприємств, установ та організацій необхідну інформацію для здійснення своїх правоохоронних функцій, а встановлені в законах спеціальні підстави та чіткі повноваження щодо витребування у кредитної організації інформації, що містить банківську таємницю.

Щодо цього вважаю також за необхідне окремо передбачити оперативні підрозділи як суб'єкти отримання інформаціі, що містять банківську таємницю, у Законі України «Про банки і банківську таємницю».

Висновки і перспективи подальших досліджень. Виходячи з того, що інститут банківської таємниці $€$ важливим чинником збереження балансу між приватними та публічними інтересами у державі, враховуючи тенденцію національного та міжнародного законодавства до лібералізації та спрощення порядку отримання інформаціі,, що містить банківську таємницю, зазначаємо, що реалізація принципів дотримання банківської таємниці потребує неухильного дотримання процесуальних норм законодавства, яке регламентує порядок отримання відомостей, які містять банківську таємницю. 3 урахуванням імплементації норм міжнародного законодавства щодо правового режиму банківської таємниці потребують подальшого удосконалення норми національного законодавства 3 цього питання задля встановлення чіткої та детальної регламентації порядку отримання інформації, що містить банківську таємницю, правоохоронними органами, а також удосконалення механізму взаємодіі правоохоронних органів України з банківськими установами під час надання відомостей, що містять банківську таємницю, у ході досудового розслідування.

У статті розглянуто порядок розкриття інформації, що містить банківську таємницю, на вимогу правоохоронних органів у контексті законодавчих змін з цього питання, які відбулися у 2019 році в законодавстві України. Проаналізовано суб'єктний склад державних правоохоронних органів та підстави для отримання такої інформації для кожного з иих органів окремо. Акиентовано увагу на вимогах, які висуваються до форми та змісту, яким має відповідати запит правоохоронних органів щодо отримання інформації, що містить банківську таємницюю у процесі виконання ними своїх владних повноважень.

Розглянуто питання отримання інформаціï, щзо містить банківську таємницю, у судовому порядку згідно з вимогами кримінально-процесуального законодавства у разі відмови банківської установи у наданні такої інформаціі на підставі вимоги. Проаналізовано підстави для такого звернення до суду й порядок виконання судового рішення. 
На основі аналізу суб'єктного складу державних правоохоронних органів, уповноважених згідно із законодавством на отримання такої інформаціі, необхінності дотримання форми та змісту звернення з такою вимогою, аналізу змісту інформаціі, яка може бути надана на підставі такого запиту, визначено недоліки порядку отримання інформаціі на підставі вимоги та запропоновано внесення відповідних змін у законодавство України.

У статті порушено питання більш чіткого врегулювання питання стосовно порядку та підстав отримання інформацї, що містить банківську таємницю, оперативними підрозділами иляхом внесення відповідних змін у Закон України «Про оперативно-розшукову діяльність» щодо повноважень таких підрозділів та у Закон України «Про банки $і$ банківську таємнищю», щзо передбачає оперативні підрозділи як суб'єкти отримання інформаціі, щзо містить банківську таємницюю.

Запропоновано внесення змін до Закону України «Про банки та банківську діяльність» у вигляді прямого посилання у Законі на наявність інформації щзодо кримінального правопорушення, вчиненого конкретною особою (юридичною або фізичною), внесеноӥ до Единого реєстру досудових розслідувань, як підстави для отримання інформаціï, щуо містить банківську таємницүю, уповноваженими суб'єктами.

Ключові слова: банківська таємниця, підстави отримання банківської таємниці, порядок розкриття банківської таємниці, вимога, правоохоронні органи.

Kucheruk G. New view on the procedure for disclosure of banking secrets to law enforcement authorities in the context of the last legislative changes

The article considers the procedure for disclosing information containing banking secrecy at the request of law enforcement agencies in the context of legislative changes on this issue, which occurred in 2019 in the legislation of Ukraine. The subjective composition of state law enforcement agencies and the grounds for obtaining such information for each of these bodies are analyzed separately. Emphasis is placed on the requirements for the form and content that must be met by law enforcement requests for information containing banking secrecy in the exercise of their authority.

The issue of obtaining information containing banking secrecy in court in accordance with the requirements of criminal procedure legislation in case of refusal of a banking institution to provide such information on the basis of the requirement is considered. The grounds for such an appeal to the court and the procedure for execution of a court decision are analyzed.

Based on the analysis of the subject composition of state law enforcement agencies authorized by law to obtain such information, the need to comply with the form and content of the request, analysis of the content of information that can be provided on the basis of such a request, identified shortcomings and proposed amendments to the legislation of Ukraine to regulate the receipt of information containing banking secrecy.

The article raises the issue of clearer regulation of the procedure and grounds for obtaining information containing banking secrecy by operational units by amending the laws of Ukraine "On operational and investigative activities" on the powers of such units and the Law of Ukraine "On Banks and Banking secrecy", providing for operational units as the subject of obtaining information containing banking secrecy.

It is proposed to amend the Law of Ukraine "On Banks and Banking" in 
the form of a direct reference in the law to the availability of information on a criminal offense committed by a particular person (legal or natural) entered in the Unified Register of Pre-trial Investigations as a basis for obtaining information banking secrecy by authorized entities.

Key words: banking secrecy, grounds for obtaining bank secrecy, the order of disclosing bank secrecy, requirement, law enforcement agencies.

\section{Література}

1. Конституція України від 28 червня 1996рокy.URL:https: / / zakon.rada.gov.ua/ laws / show/ $254 \%$ D O \% BA/ 96-\% D0\% B2\% D1\% 80\#Text.

2. Самсонова O.A. Получение органами предварительного расследования и судом информации, составляющей банковскую тайну : автореф. дисс. ... канд. юрид. наук : спец. 12.00 .09 «Уголовный процесс, криминалистика и судебная экспертиза, оперативно-розыскная деятельность». Иркутск, 2003. 22 c.

3. Фаткина Е.В. Правова природа банковской тайны : автореф. дисс. ... канд. юрид. наук : спеи. 12.00 .03 «ражданское право; предпринимательское право; семейное право, международное частное право». Москва, 2015. 32 с.

4. Про захист персональних даних : Закон України від 1 червня 2010 року № 2297-VI. URL: https: / / zakon. rada.gov.ua/laws/show/2297-17\#Text.

5. Про інформацію : Закон України від 2 жовтня 1992 року № 2657-ХIII. URL: https: / / zakon.rada.gov.ua/laws/ show/2657-12\#Text.

6. Про національну безпеку України : Закон України від 21 червня 2018 року № 2469-VIII. URL: https://zakon.rada. gov.ua/laws/show/2469-19\#Text.

7. Про банки і банківську діяльність : Закон України від 7 грудня
2000 року № 2121-III. URL: https: / / zakon. rada.gov.ua/laws/show/2268-19\#Text.

8. Корнієнко М.В. Сучасні засади протидіi спеціалізованих підрозділів ОВС організованій злочинності : монографія. Київ, 2003. 676 c.

9. Кримінально-процесуальнии кодекс України від 13 квітня 2012 року № 4651 VI. URL: https://zakon.rada.gov.ua/ laws/show/4651-17\#Text.

10. Постанова Верховного Суду України від 20 лютого 2018 року у справі № 910/8001/17. URL: https:// protocol.ua/ua/postanova_kgs v $p_{-} v i d_{-} 20_{-} 02_{-} 2018_{-} r o k u_{-} u_{-}$ spravi_910_8001_17.

11. Про затвердження Змін до Правил зберігання, захисту, використання та розкриття банківської таємниці : Постанова Правління Національного банку України від 31 січня 2020 року № 13. URL: https: / / zakon.rada.gov.ua/ laws / show/v0013500-20\#Text.

12. Про затвердження Правил зберігання, захисту, використання та розкриття банківської таємниці : Постанова Правління Національного Банку України від 14 липня 2006 року № 267. URL: https: / / zakon.rada.gov.ua/laws / show/z0935-06\#Text.

13. О банках и банковской деятельности в Республике Казахстан : Закон Республики Казахстан om 31 августа 1995 года № 2444. URL: https://online.zakon.kz/document/?doc_ $i d=1003931$ \# pos $=5 ;-106$.

14.Банковский кодекс Республики Белорусь от 25 октября 2000 года № 441-3. URL: https://kodeksy-by.com/ bankouskij_kodeks_rb.htm.

15. Чернявський С.С., Алексєєва-Проияюк Д.О. Удосконалення порядку розкриття інформації, що містить банківську таємницю, у контексті реформування кримінального судочинства. Науковий вісник Національної академії внутрішніх справ. 2012. № 2. С.122. 